\title{
Roles of zinc and metallothionein-3 in oxidative stress-induced lysosomal dysfunction, cell death, and autophagy in neurons and astrocytes
}

\author{
Sook-Jeong Lee ${ }^{2}$, Jae-Young Koh ${ }^{1 *}$
}

\begin{abstract}
Zinc dyshomeostasis has been recognized as an important mechanism for cell death in acute brain injury. An increase in the level of free or histochemically reactive zinc in astrocytes and neurons is considered one of the major causes of death of these cells in ischemia and trauma. Although zinc dyshomeostasis can lead to cell death via diverse routes, the major pathway appears to involve oxidative stress.

Recently, we found that a rise of zinc in autophagic vacuoles, including autolysosomes, is a prerequisite for lysosomal membrane permeabilization and cell death in cultured brain cells exposed to oxidative stress conditions. The source of zinc in this process is likely redox-sensitive zinc-binding proteins such as metallothioneins, which release zinc under oxidative conditions. Of the metallothioneins, metallothionein-3 is especially enriched in the central nervous system, but its physiologic role in this tissue is not well established. Like other metallothioneins, metallothionein-3 may function as metal detoxicant, but is also known to inhibit neurite outgrowth and, sometimes, promote neuronal death, likely by serving as a source of toxic zinc release. In addition, metallothionein-3 regulates lysosomal functions. In the absence of metallothionein-3, there are changes in lysosome-associated membrane protein-1 and -2 , and reductions in certain lysosomal enzymes that result in decreased autophagic flux. This may have dual effects on cell survival. In acute oxidative injury, zinc dyshomeostasis and lysosomal membrane permeabilization are diminished in metallothionein-3 null cells, resulting in less cell death. But over the longer term, diminished lysosomal function may lead to the accumulation of abnormal proteins and cause cytotoxicity.

The roles of zinc and metallothionein-3 in autophagy and/or lysosomal function have just begun to be investigated. In light of evidence that autophagy and lysosomes may play significant roles in the pathogenesis of various neurological diseases, further insight into the contribution of zinc dynamics and metallothionein-3 function may help provide ways to effectively regulate these processes in brain cells.
\end{abstract}

\section{Introduction}

Cells have two major protein degradation pathways: the ubiquitin-proteasome system (UPS), which mainly acts to clear and recycle short-lived proteins [1], and macroautophagy or autophagy, in which lysosomal degradation is the final event [2]. This latter pathway degrades waste proteins and organelles, recycling damaged organelles and large proteins that cannot be processed via the UPS. The autophagic pathway usually operates at low levels under normal conditions, but is rapidly upregulated under stress conditions, such as starvation, hormonal

\footnotetext{
* Correspondence: jkko@amc.seoul.kr

${ }^{1}$ Neural Injury Research Center, Department of Neurology, Asan Institute for Life Science, University of Ulsan, College of Medicine, Seoul 138-736, Korea Full list of author information is available at the end of the article
}

imbalances, and oxidative stress [2-4]. Whereas autophagic degradation releases free amino acids and fatty acids that serve to meet the energy demands of cells in starvation [5], it also removes potentially detrimental abnormal organelles and misfolded proteins [6].

During the last decade, abnormalities in autophagy have been suggested to play roles in the pathogenesis of cancer and neurodegenerative disease, among other disorders [7-15]. For instance, a reduction in autophagy is observed in various cancer cells [16-18], and internal or external activators of autophagy, such as Beclin-1 (BECN1), transforming growth factor- $\beta$ (TGF- $\beta$ ), and rapamycin, have been shown to effectively reduce tumor mass in human hepatocellular carcinoma cells and xenografted breast cancer cell lines [19-21]. There is also 
evidence for reduced or blocked autophagy in various neurodegenerative conditions, including Alzheimer's disease, Parkinson's disease, Niemann-Pick type $\mathrm{C}$ disease, and Huntington's disease [22-26]. Consistent with this, downregulation of autophagy-activating genes in the brain results in severe neurodegeneration $[23,27,28]$. Given the potential clinical importance of autophagy, there has been rapidly increasing interest in investigating this process in various disease models.

Recently, we reported that zinc and metallothionein 3 (MT3) have modulatory effects on autophagic vacuole (AV) formation and lysosomal changes in cultured brain cells [29-31]. Zinc serves many essential functions in the body under normal conditions; it is enriched in all cells, and is absolutely required for cellular development and survival [32,33]. Accordingly, a severe zinc deficiency causes developmental anomalies in humans and animals [34-36]. On the other hand, increased free zinc levels in a cell can be highly cytotoxic. The toxic role of endogenous zinc has been extensively studied, especially in the context of acute brain injury [37-41], where zinc has been shown to be capable of causing cell death through diverse mechanisms. For instance, high levels of intracellular free zinc can activate protein kinase $\mathrm{C}$ (PKC), nicotinamide adenine dinucleotide phosphate (NADPH) oxidases [42], p38 mitogen-activated protein kinase (MAPK) [43-45], poly ADP-ribose polymerase (PARP) $[46,47], \mathrm{p} 75^{\mathrm{NTR}}$-associated death executor $\left(\mathrm{p} 75^{\mathrm{NTR}} /\right.$ NADE), and apoptosis-inducing factor (AIF) [48-50].

Because cells are vulnerable to drastic changes in intracellular free zinc, they are equipped with a number of proteins that function to regulate zinc levels. For instance, zinc transporters (ZnTs) and Zrt- and Irt-like proteins (ZIPs) function to transfer zinc across membranes [51,52]. In addition, cysteine-rich metallothioneins may function as zinc buffers inside cells. Of the metallothioneins (MTs), MT3 is especially enriched in the brain [53,54]. Some MT3 zinc-binding sites are redox modulated, allowing MT3 to accept and release zinc in response to changes in oxidative status [53-57]. Because MT3 can induce or reduce zinc toxicity depending on context, it may increase or decrease brain injury, depending on the particular state of MT3. For example, if apo-forms are predominant, MT3 may accept zinc, acting as a buffer against rising intracellular zinc levels. In contrast, if zinc-binding cysteine residues of MT3 are oxidized, MT3 may release zinc and cause more cell death.

However, our recent findings suggest that MT3 may have more complex effects on cell biology than simply functioning as a zinc buffer. For instance, astrocytes from MT3-null mice show altered activity of lysosomes-the endpoint in the autophagy pathway [31]. Here, we review the possible roles of zinc and MT3 in autophagy activation and lysosomal changes under oxidative stress conditions.

\section{Increases in Zinc under Oxidative Stress Conditions: Role in Neuronal and Glial Cell Death}

The central nervous system contains high levels of zinc, which is present at about $70-80 \mathrm{ppm}$ in gray matter [58]. Whereas the majority of brain zinc is tightly bound to proteins, about $10-20 \%$ is localized to certain glutamatergic vesicles in a relatively free state (chelatable zinc) [59-61]. This synaptic zinc may be released upon neuronal activation, and is involved in signal transmission/transduction across synapses [35,62-65]. However, in acute brain injury, the rise of intracellular free zinc levels contributes to neuronal and astrocytic cell death [37,66-70]. For example, zinc-induced neurotoxicity is observed following acute brain injury, such as trauma, seizures, and ischemia $[35,37,38,71-75]$. Whereas synaptic zinc may trigger toxic cascades in areas such as the hippocampal CA3 region, where synaptic zinc is especially enriched in mossy fiber terminals [76,77], intracellular zinc release may play a larger role in most other brain regions [77-79].

Calcium-overload excitotoxicity is still considered to be the major mechanism of neuronal death in acute brain injuries, including focal ischemia [80-82]. However, calcium excitotoxicity alone may not be a sufficient to produce infarcts, in which astrocytes and oligodendrocytes, which are much less vulnerable to glutamate [83-85], are also severely damaged. Hence, factors that contribute to non-neuronal cell death need to be identified. In our previous study, we found that the infarct core exhibits markedly increased levels of labile zinc in all cellular elements $[86,87]$, raising the possibility that zinc toxicity may contribute to infarct formation. In fact, oxidative stress, which usually accompanies focal ischemia, induces increases in labile zinc in astrocytes as well as neurons $[37,88-90]$.

So, which toxic mechanisms does zinc trigger inside cells? Studies over the last decade have suggested a number of different mechanisms that may mediate zinc neurotoxicity. Activation of PKC, NADPH oxidases, extracellular signal regulated kinase $1 / 2$ (ERK-1/2), and PARP by zinc has been shown to cause mainly oxidative neuronal necrosis $[35,42]$. In addition, caspase-mediated apoptosis is induced by the activation of the $\mathrm{p} 75^{\mathrm{NTR}} /$ NADE pathway and by AIF released from mitochondria in zinc-exposed neurons $[48-50,91]$.

\section{Lysosomal Membrane Permeabilization and Zinc}

In addition to the above-mentioned mechanisms for zinc toxicity, we have recently presented evidence that lysosomal changes may underlie zinc-induced cell death (Figure 1) [29]. The lysosome is an acidic cytosolic 
A

Normal Autophagy

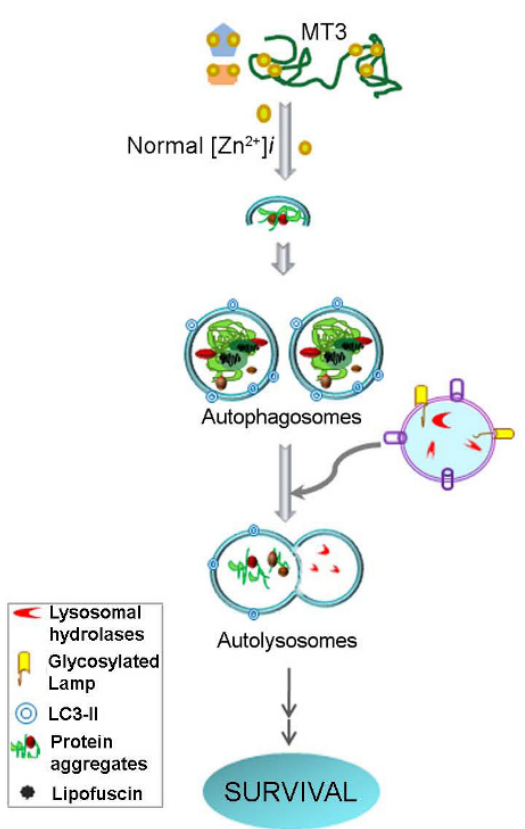

B

Excess Autophagy \& LMP
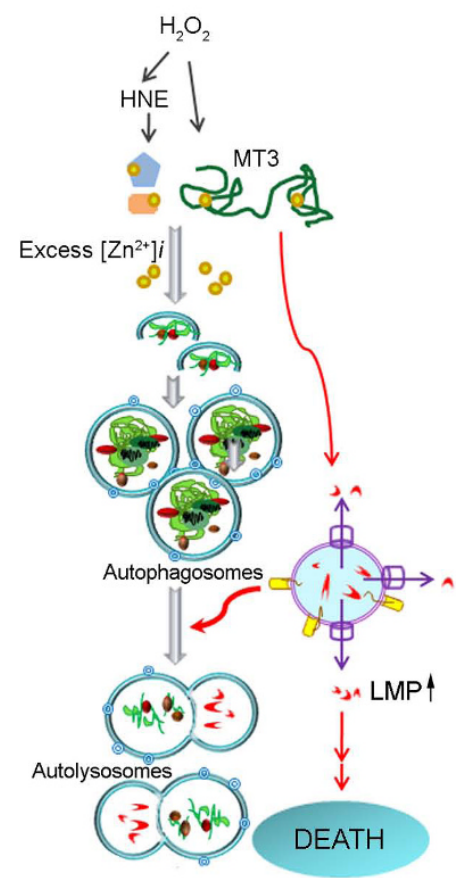

C

Defective Autophagy
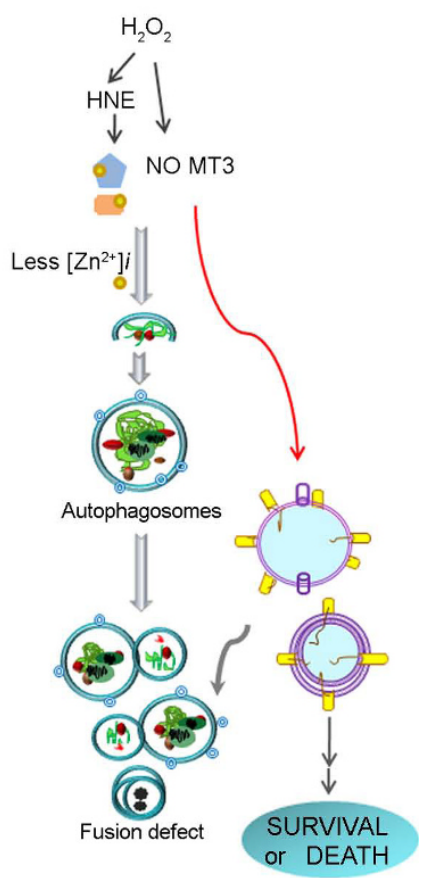

Figure 1 Summary diagram depicting zinc and MT3 effects on autophagy and lysosomes. A. Under physiological conditions, normal signaling involving zinc release from MT3 contributes to the normal progression of autophagy, resulting in the degradation of abnormal protein aggregates and waste organelles. This pathway may be beneficial for cell survival. B. Under injurious oxidative stress conditions (e.g., $\mathrm{H}_{2} \mathrm{O}_{2}$ or HNE treatment), the events described in (A) are exaggerated. Hence, much more intense zinc release from MT3 is induced, and excess autophagy is activated. Excess autophagy and excess zinc accumulation in lysosomes ultimately leads to LMP and cell death. C. Downregulation of MT3 decreases zinc release from MT3, inhibiting lysosomal functions and reducing fusion between autophagosomes and lysosomes, resulting in a reduced autophagy flux. Under conditions of acute injury, this results in a reduction in both LMP and cell death, but it can be detrimental to cell survival under conditions of chronic stress by reducing autophagic degradation of abnormal proteins.

vesicle that contains numerous (>80) acidic hydrolasesglycosidases, phosphatases, proteases, nucleases, peptidases, sulphatases and lipases-that collectively are capable of degrading all cellular components. As such, the lysosome serves as the main degradative factory in cells, receiving cargoes from phagosomes, endosomes, and autophagosomes. Because lysosomal acidic hydrolases are so potent, their release in combination with cytosolic acidification can cause cell death through severe breakdown of cellular components as well as activation of cell death inducers, such as BID. This process is termed lysosomal membrane permeabilization (LMP) [92].

LMP has been shown to occur in cell death caused by oxidative stress, calcium overload, p53 activation, and exposure to lysosomotrophic toxins such as sphingosine [92,93]. Moreover, several cancer chemotherapeutic agents have been shown to induce lysosomal changes, including LMP, in diverse cancer cell types [2]. In the brain, epileptic injury and ischemic injury may cause LMP in certain neurons, inducing their death $[5,8,29]$, and lysosomal enzyme inhibitors may be neuroprotective against ischemic insults [94-96].

Recently, we presented evidence that LMP is a key contributor to oxidative and zinc-induced hippocampal neuronal death [29]. The salient features of this mechanism are as follows: Under normal conditions, free zinc levels in lysosomes are low. Following exposure to $\mathrm{H}_{2} \mathrm{O}_{2}$ or toxic levels of zinc, the level of zinc in lysosomes rises rapidly and significantly. Next, a substantial fraction of zinc-laden lysosomes undergo membrane disintegration, releasing enzymes such as cathepsins. Finally, hippocampal neuronal death occurs in a zinc- and cathepsin-dependent manner. These results indicate that zinc-overload in lysosomes and lysosomal disruption are key events in oxidative neuronal death (Figure 1). Interestingly, lysosomes also accumulate 4-hydroxy-2-nonenal (HNE) adducts in a zinc-dependent manner, and HNE per se causes LMP, suggesting that HNE may be one of mediators of lysosomal derangement in oxidative and/or zinc-mediated neuronal death (Figure 1). Further studies will be needed to 
firmly establish the relationship between known signaling events in zinc toxicity and LMP.

The role of various organelles in cell death has been extensively studied in recent years. Initially, the focus was on mitochondria, since this organelle is the main site of reactive oxygen species (ROS) generation and because it also contains and/or releases several apoptosis-regulating molecules, including B-cell lymphoma 2 (Bcl-2), Bcl-2-associated X protein (Bax), AIF, and cytochrome c [15]. More recently, the endoplasmic reticulum (ER) has received increasing research attention. ER stress plays an integral role in the unfolded proteininduced alarm system that activates multiple signaling pathways, including MAPK, c-Jun N-terminal kinase (JNK), p38 MAPK, and nuclear factor- $\kappa \mathrm{B}(\mathrm{NF}-\kappa \mathrm{B})$ pathways [97-101]. Similarly, a recent surge in interest in autophagy has brought the lysosome to the fore as another organelle with a major role to play in cell death mechanisms. In this context, the possibility that cellular free zinc may function as a link between oxidative stress and LMP is particularly intriguing.

Then what is the mechanism underlying lysosomal zinc accumulation? One possible answer is that the accumulation of zinc in lysosomes may be an exaggerated version of a normal physiologic event, involving the transport of zinc from the cytosol via certain metal transporters or ionophores. In this case, zinc may serve as an activator of lysosomal functions. Alternatively, zinc accumulation may merely be a result of lysosomal activation, reflecting zinc release from various zinc-binding proteins inside lysosomes. Although it is unclear which is the case, the demonstration that the cell-permeant zinc chelator TPEN (tetrakis[2-pyridylmethyl] ethylenediamine) not only blocks the rise in free zinc levels in lysosomes but also inhibits LMP tends to favor the former possibility. The precise inter-organelle zinc dynamics within cells warrant further investigation.

\section{Autophagy and Zinc}

The finding that zinc dyshomeostasis is closely connected to lysosomes, the effector organelle for autophagy, prompted us to investigate the possible role of zinc in the entire autophagic cascade. Autophagy means "self-eating" in Greek [6,102]. It is evolutionally conserved in all eukaryotes and serves the essential self-digestive function of degrading large proteins and organelles [3,103].

Of the three known types of autophagy-macroautophagy, microautophagy, and chaperone-mediated autophagy $[6,104,105]$-macroautophagy (or simply autophagy) is the best characterized. Recent advances in the molecular biology of autophagy have led to the identification of a number of proteins required for this process, including the autophagy-related homologs, BECN1 and
ATG5. Microtubule-associated membrane protein-II (LC3-II), another autophagy-related protein, is inserted into the outer membrane of autophagosomes and has been used as a marker for autophagic activation [106,107]. LC3-II is quite stable and hence easy to detect. Transfection with GFP- or RFP-LC3 has been widely used to monitor the autophagic process in living cells.

Recently, we used this approach in cultured astrocytes, which are easier to transfect than primary neurons. In astrocytes, inducers of oxidative stress such as $\mathrm{H}_{2} \mathrm{O}_{2}$ or $\mathrm{FeCl}_{2}$ activate autophagy, as evidenced by increased LC3-II levels and autophagosome formation (Figure 1). Interestingly, zinc accumulation occurs in autophagosomes as it does in lysosomes [30]. Importantly, TPEN blocks the activation of autophagy by oxidative stress, suggesting that zinc accumulation has already started at the level of autophagosomes and plays a role in autophagy progression. It is not yet known whether specific zinc transporters are responsible for the zinc accumulation. Moreover, it is possible that TPEN effect is not due to chelation of zinc inside autophagosomes, but may instead reflect effects on upstream elements in the signaling cascade, such as inhibition of phosphatidylinositol 3-kinase type III (PI3K type III) activation. In either case, these data represents the first demonstration that cellular zinc may play a role in activation of the autophagic process. Whether autophagy thus activated is functional (i.e., increases autophagic flux) will require additional study; however, the fact that mutant huntingtin protein (mHttp) aggregation is reduced under these conditions suggests that this may be the case.

One interesting question is whether the role of zinc in autophagy and LMP is limited to brain cells or is more generally applicable to other cell types. The fact that tamoxifen-induced autophagic cell death in MCF-7 breast cancer cells [14] exhibits similar features, such as zinc accumulation in AVs and LMP $[29,30]$, suggests that zinc may play a role in autophagy and autophagic cell death in general. If confirmed, which will require addition testing in other cell types and diverse models, modulation of zinc levels may prove to be an effective therapeutic intervention under conditions in which abnormalities in autophagy are contributing factors, such as cancer and neurodegenerative disorders.

\section{MT3: the Source for Zinc in Neurons and Astrocytes}

Human genome analyses have revealed that more than a thousand proteins may contain zinc-binding motifs [108]. However, most of these proteins bind zinc tightly, and hence may not normally contribute to fast zinc dynamics in cells. In contrast, some proteins, such as MTs, contain zinc-binding sites that are highly sensitive to redox states [25,109-114]. When cells are exposed to 
reducing conditions or when cellular free zinc levels rise, apo-forms of MTs (thioneins) may bind more zinc. Conversely, under conditions in which cells are exposed to oxidative stress and during signaling events involving ROS generation, MTs may serve as zinc-donors, raising free zinc levels (Figure 1) [114]. Consistent with this, diverse cells exhibit a rise in free zinc levels in response to stressful extracellular or intracellular stimuli, including hormones, cytokines, metals, inflammation, oxidative agents, and other stresses [115-118]. This increase in free zinc may stimulate diverse cellular-response signals $[109,110,119,120]$

Four isoforms of MT, MT1-4, have been identified in mammals, all of which have seven metal binding domains [113,121-124]. MT1 and MT2 are ubiquitously expressed in all tissues. In contrast, MT3 and MT4 are expressed mainly (although not exclusively) in the central nervous system and squamous epithelia [125-128]. Hence, it is likely that, at least in the brain, MT3 may serve as a key source for dynamically exchangeable zinc in cells exposed to various stress stimuli.

MT3 was originally identified as a neuronal growth inhibitory factor that inhibited outgrowth of rat cortical neurons in the presence of Alzheimer's disease brain extracts [57]. This effect is not shared by MT1 or MT2, and is probably due to the unique presence of a TCPCP motif within the $\beta$-domain of MT3 [117,122,129-131]. The precise mechanism underlying the neurite outgrowth-inhibitory effect of MT3 remains poorly understood, but a number of studies have implicated MT3 in various neurological conditions. Altered MT3 expression has been also reported in amyotrophic lateral sclerosis (ALS) [54], Down syndrome [132], pontosubicular necrosis [133], Parkinson's disease, meningitis, and Creutzfeld-Jakob disease [134].

In addition, MT3 appears to exert both protective and injury-promoting effects in experimental models of brain injury. The neuroprotective effects of MT3, which are presumably due to its metal-chelating and antioxidative effects, are evident in epileptic brain injury [135], cortical cryolesions [136], a mutant superoxide dismutase 1 (SOD1[G93A]) mouse model of ALS [137], and peripheral nerve injury [138]. Several researchers have demonstrated the opposite phenomenon, showing for example that intracellular zinc released from MT3 may trigger neuronal death in vivo [77] and in vitro [31], indicating the injury-promoting effects of MT3 $[54,56]$.

In adult brains, MT3 is predominantly expressed in neurons, but in developing brains it is also significantly expressed in astrocytes. We have demonstrated that the increase in intracellular free zinc induced by oxidative injury is significantly reduced in cultured MT3-null astrocytes compared with wild-type cells (Figure 1) [31]. Moreover, cell death is also attenuated in MT3-null cells. These results provide additional support for the idea that MT3 is the main source for elevations in toxic free zinc in acute brain injury. Interestingly, although astrocytes express substantial amounts of MT1 and MT2 [120], experiments employing small interfering RNAs suggest that these MTs do not participate as zinc donors.

\section{Regulation of Lysosomal Functions by MT3}

MT3 may have complex biological functions that extend well beyond its role as a simple buffer for zinc, as exemplified by its initial identification as a neuronal growth inhibitory factor. Recently, we found that MT3 may regulate the levels of lysosomal proteins, thus regulating the function of lysosomes [31]. Specifically, the absence of MT3 in astrocytes results in changes in the levels of LMP and altered LMP glycosylation patterns (Figure 1). Such changes may inhibit docking of upstream vesicles, such as autophagosomes and endosomes, to lysosomes. In fact, the levels of autophagic markers such as LC3-II are markedly increased in astrocytes from MT3-null mice (Figure 1).

Another interesting change induced by the absence of MT3 is a reduction in certain hydrolase activities that implies a decrease in lysosomal protein degradative capability. The combination of reduced zinc levels and reduced lysosomal enzyme levels may act to attenuate LMP and cell death (Figure 1). Moreover, decreased lysosomal function should lead to diminished autophagic flux. Consistent with this, we found that cholesterol metabolism was altered and mHttp aggregates accumulated in the absence of MT3 [31].

How does MT3 regulate lysosomal functions? Although the available information provides little insight into this question, one report notes that disruption of c-Abl, a member of the Abelson family of cytoplasmic non-receptor tyrosine kinases, has effects on lysosomes in the A549 alveolar carcinoma cell line that are similar to those observed in brain cells lacking MT3 [139]. This suggests that MT3 may be involved in the c-Abl signaling cascade in brain cells. Alternately, adequate free zinc levels may be required to maintain normal lysosomal function. Further studies may help determine the mechanism(s) underlying MT3 effects on lysosomes. Regardless of the mechanism, because lysosomal function is linked to autophagy and neurodegenerative disorders, MT3 may prove to be a suitable target for drugs designed to control lysosomal function. By reducing toxic zinc accumulation, LMP, and cell death, downregulation of MT3 function may be beneficial in acute brain injury (Figure 1). Conversely, in neurodegenerative conditions in which the accumulation of protein aggregates contributes to the pathology, upregulation of MT3, and the associated enhancement in lysosomal 
function and protein degradation, may be beneficial (Figure 1).

\section{Conclusions}

Recent studies have revealed that free zinc levels change in various organelles in response to physiologic or pathological stimuli, and suggest important functional consequences of these zinc dynamics. One aspect of this larger picture-the possible roles of free zinc in autophagic and lysosomal functions-has been the focus of this review. Under oxidative stress conditions, free zinc levels in the cytosol and lysosomes of cultured neurons and astrocytes rise, ultimately resulting in LMP and cell death. While this change may contribute to the cell death that occurs after acute brain injury, the fact that free zinc levels rise in AVs (autophagosomes and autolysosomes) following various stimuli is also notable. Because reducing the levels of free zinc with TPEN blocks all these changes, the rise of free zinc in AVs may play a role in the progression of the autophagic cascade. In brain cells, the source of free zinc may be MT3. In support of a role for MT3 in lysosomal function, the absence of MT3 results in drastic changes in the levels of lysosomal proteins and results in reduced lysosomal degradative capacity. Further studies will be needed to elucidate the mechanism by which MT3 regulates lysosomal functions.

\section{Acknowledgements}

This work was supported by the Korea Scicence and Engineering Foundation (KOSEF) through the National Research Lab Program (KOSEF 2010-0002152 and KOSEF 2010-0007999), by a Korea Research Foundation Grant (MOEHRD 2009-0093836) funded by the Korean Ministry of Education and Human Resources Development.

\section{Author details}

'Neural Injury Research Center, Department of Neurology, Asan Institute for Life Science, University of Ulsan, College of Medicine, Seoul 138-736, Korea. ${ }^{2}$ Neural Injury Research Center, Asan Institute for Life Science, University of Ulsan, College of Medicine, Seoul 138-736, Korea.

\section{Authors' contributions}

All authors participated in developing and discussing the ideas, integrating the information, and writing the manuscript. All authors have read and approved the final manuscript.

\section{Competing interests}

The authors declare that they have no competing interests.

Received: 24 September 2010 Accepted: 26 October 2010 Published: 26 October 2010

\section{References}

1. Nedelsky NB, Todd PK, Taylor JP: Autophagy and the ubiquitinproteasome system: collaborators in neuroprotection. Biochim Biophys Acta 2008, 1782:691-699.

2. Kroemer $\mathrm{G}$, Jaattela M: Lysosomes and autophagy in cell death control. Nat Rev Cancer 2005, 5:886-897.

3. Farre JC, Subramani S: Peroxisome turnover by micropexophagy: an autophagy-related process. Trends Cell Biol 2004, 14:515-523.
4. Kundu M, Thompson CB: Autophagy: basic principles and relevance to disease. Annu Rev Pathol 2008, 3:427-455.

5. Yamashima T, Oikawa S: The role of lysosomal rupture in neuronal death. Prog Neurobiol 2009, 89:343-358.

6. Mizushima N, Levine B, Cuervo AM, Klionsky DJ: Autophagy fights disease through cellular self-digestion. Nature 2008, 451:1069-1075.

7. Yue Z, Wang QJ, Komatsu M: Neuronal autophagy: going the distance to the axon. Autophagy 2008, 4:94-96.

8. Windelborn JA, Lipton P: Lysosomal release of cathepsins causes ischemic damage in the rat hippocampal slice and depends on NMDAmediated calcium influx, arachidonic acid metabolism, and free radical production. J Neurochem 2008, 106:56-69.

9. Uchiyama Y, Koike M, Shibata M, Sasaki M: Autophagic neuron death. Methods Enzymol 2009, 453:33-51.

10. Levine B: Cell biology: autophagy and cancer. Nature 2007, 446:745-747.

11. Levine B, Kroemer G: Autophagy in the pathogenesis of disease. Cell 2008, 132:27-42.

12. Liu C, Gao Y, Barrett J, Hu B: Autophagy and protein aggregation after brain ischemia. J Neurochem 2010, 115:68-78.

13. Huang C, Yitzhaki S, Perry CN, Liu W, Giricz Z, Mentzer RM Jr, Gottlieb RA: Autophagy induced by ischemic preconditioning is essential for cardioprotection. J Cardiovasc Transl Res 2010, 3:365-373.

14. Hwang JJ, Kim HN, Kim J, Cho DH, Kim MJ, Kim YS, Kim Y, Park SJ, Koh JY Zinc(II) ion mediates tamoxifen-induced autophagy and cell death in MCF-7 breast cancer cell line. Biometals.

15. Chakrabarti L, Eng J, Ivanov N, Garden GA, La Spada AR: Autophagy activation and enhanced mitophagy characterize the Purkinje cells of pcd mice prior to neuronal death. Mol Brain 2009, 2:24.

16. Gozuacik D, Kimchi A: Autophagy as a cell death and tumor suppressor mechanism. Oncogene 2004, 23:2891-2906.

17. Yousefi S, Simon HU: Autophagy in cancer and chemotherapy. Results Probl Cell Differ 2009, 49:183-190.

18. Kisen GO, Tessitore L, Costelli P, Gordon PB, Schwarze PE, Baccino FM, Seglen PO: Reduced autophagic activity in primary rat hepatocellular carcinoma and ascites hepatoma cells. Carcinogenesis 1993, 14:2501-2505.

19. Huynh H, Teo CC, Soo KC: Bevacizumab and rapamycin inhibit tumor growth in peritoneal model of human ovarian cancer. Mol Cancer Ther 2007, 6:2959-2966.

20. Kiyono K, Suzuki HI, Matsuyama H, Morishita Y, Komuro A, Kano MR, Sugimoto K, Miyazono K: Autophagy is activated by TGF-beta and potentiates TGF-beta-mediated growth inhibition in human hepatocellular carcinoma cells. Cancer Res 2009, 69:8844-8852.

21. Liang XH, Jackson S, Seaman M, Brown K, Kempkes B, Hibshoosh H, Levine $B$ : Induction of autophagy and inhibition of tumorigenesis by beclin 1. Nature 1999, 402:672-676.

22. Liao G, Yao Y, Liu J, Yu Z, Cheung S, Xie A, Liang X, Bi X: Cholesterol accumulation is associated with lysosomal dysfunction and autophagic stress in Npc1 -/- mouse brain. Am J Pathol 2007, 171:962-975.

23. Pan T, Kondo S, Le W, Jankovic J: The role of autophagy-lysosome pathway in neurodegeneration associated with Parkinson's disease. Brain 2008, 131:1969-1978.

24. Winslow AR, Rubinsztein DC: Autophagy in neurodegeneration and development. Biochim Biophys Acta 2008, 1782:723-729.

25. Cheung $Z \mathrm{ZH}, \mathrm{lp}$ NY: The emerging role of autophagy in Parkinson's disease. Mol Brain 2009, 2:29.

26. Lorenzen A, Samosh J, Vandewark K, Anborgh PH, Seah C, Magalhaes AC, Cregan SP, Ferguson SS, Pasternak SH: Rapid and direct transport of cell surface APP to the lysosome defines a novel selective pathway. $\mathrm{Mol}$ Brain 2010, 3:11.

27. Hara T, Nakamura K, Matsui M, Yamamoto A, Nakahara Y, SuzukiMigishima R, Yokoyama M, Mishima K, Saito I, Okano H, et al: Suppression of basal autophagy in neural cells causes neurodegenerative disease in mice. Nature 2006, 441:885-889.

28. Lee JA: Autophagy in neurodegeneration: two sides of the same coin. BMB Rep 2009, 42:324-330

29. Hwang JJ, Lee SJ, Kim TY, Cho JH, Koh JY: Zinc and 4-hydroxy-2-nonenal mediate lysosomal membrane permeabilization induced by $\mathrm{H} 2 \mathrm{O} 2$ in cultured hippocampal neurons. J Neurosci 2008, 28:3114-3122.

30. Lee SJ, Cho KS, Koh JY: Oxidative injury triggers autophagy in astrocytes: the role of endogenous zinc. Glia 2009, 57:1351-1361. 
31. Lee SJ, Park MH, Kim HJ, Koh JY: Metallothionein-3 regulates lysosomal function in cultured astrocytes under both normal and oxidative conditions. Glia 2010, 58:1186-1196.

32. MacDonald RS: The role of zinc in growth and cell proliferation. J Nutr 2000, 130:1500S-1508S.

33. Prasad AS: Zinc in growth and development and spectrum of human zinc deficiency. J Am Coll Nutr 1988, 7:377-384.

34. Fosmire GJ, Fosmire MA, Sanstead HH: Zinc deficiency in the weanling rat: effects on liver composition and polysomal profiles. J Nutr 1976, 106:1152-1158.

35. Frederickson CJ, Koh JY, Bush Al: The neurobiology of zinc in health and disease. Nat Rev Neurosci 2005, 6:449-462.

36. Sandstead HH, Prasad AS, Schulert AR, Farid Z, Miale A Jr, Bassilly S, Darby WJ: Human zinc deficiency, endocrine manifestations and response to treatment. Am J Clin Nutr 1967, 20:422-442.

37. Koh JY, Suh SW, Gwag BJ, He YY, Hsu CY, Choi DW: The role of zinc in selective neuronal death after transient global cerebral ischemia. Science 1996, 272:1013-1016.

38. Choi DW, Koh JY: Zinc and brain injury. Annu Rev Neurosci 1998, 21:347-375.

39. Frederickson CJ, Maret W, Cuajungco MP: Zinc and excitotoxic brain injury: a new model. Neuroscientist 2004, 10:18-25

40. Capasso M, Jeng JM, Malavolta M, Mocchegiani E, Sensi SL: Zinc dyshomeostasis: a key modulator of neuronal injury. J Alzheimers Dis 2005, 8:93-108, discussion 209-115.

41. Kim EY, Koh JY, Kim YH, Sohn S, Joe E, Gwag BJ: Zn2+ entry produces oxidative neuronal necrosis in cortical cell cultures. Eur J Neurosci 1999, 11:327-334.

42. Koh JY: Zinc and disease of the brain. Mol Neurobiol 2001, 24:99-106.

43. Bossy-Wetzel E, Talantova MV, Lee WD, Scholzke MN, Harrop A, Mathews E, Gotz T, Han J, Ellisman MH, Perkins GA, et al: Crosstalk between nitric oxide and zinc pathways to neuronal cell death involving mitochondrial dysfunction and p38-activated K+ channels. Neuron 2004, 41:351-365.

44. He K, Aizenman E: ERK signaling leads to mitochondrial dysfunction in extracellular zinc-induced neurotoxicity. J Neurochem 2010, 114:452-461.

45. Seo SR, Chong SA, Lee SI, Sung JY, Ahn YS, Chung KC, Seo JT: Zn2 +-induced ERK activation mediated by reactive oxygen species causes cell death in differentiated PC12 cells. J Neurochem 2001, 78:600-610.

46. Hwang JJ, Choi SY, Koh JY: The role of NADPH oxidase, neuronal nitric oxide synthase and poly(ADP ribose) polymerase in oxidative neuronal death induced in cortical cultures by brain-derived neurotrophic factor and neurotrophin-4/5. J Neurochem 2002, 82:894-902.

47. Suh SW, Aoyama K, Alano CC, Anderson CM, Hamby AM, Swanson RA: Zinc inhibits astrocyte glutamate uptake by activation of poly(ADP-ribose) polymerase-1. Mol Med 2007, 13:344-349.

48. Mukai J, Hachiya T, Shoji-Hoshino S, Kimura MT, Nadano D, Suvanto P, Hanaoka T, Li Y, Irie S, Greene LA, et al: NADE, a p75NTR-associated cell death executor, is involved in signal transduction mediated by the common neurotrophin receptor p75NTR. J Biol Chem 2000, 275:17566-17570.

49. Park JA, Lee JY, Sato TA, Koh JY: Co-induction of p75NTR and p75NTRassociated death executor in neurons after zinc exposure in cortical culture or transient ischemia in the rat. J Neurosci 2000, 20:9096-9103.

50. Jiang D, Sullivan $P G$, Sensi SL, Steward O, Weiss JH: Zn(2+) induces permeability transition pore opening and release of pro-apoptotic peptides from neuronal mitochondria. J Biol Chem 2001, 276:47524-47529.

51. Harris ED: Cellular transporters for zinc. Nutr Rev 2002, 60:121-124.

52. Liuzzi JP, Cousins RJ: Mammalian zinc transporters. Annu Rev Nutr 2004, 24:151-172.

53. Maret $\mathrm{W}$ : The function of zinc metallothionein: a link between cellular zinc and redox state. J Nutr 2000, 130:1455S-1458S.

54. Uchida Y: Growth-inhibitory factor, metallothionein-like protein, and neurodegenerative diseases. Biol Signals 1994, 3:211-215.

55. Maret W: Cellular zinc and redox states converge in the metallothionein/ thionein pair. J Nutr 2003, 133:1460S-1462S

56. West AK, Hidalgo J, Eddins D, Levin ED, Aschner M: Metallothionein in the central nervous system: Roles in protection, regeneration and cognition. Neurotoxicology 2008, 29:489-503.

57. Uchida $Y$, Takio K, Titani $K$, Ihara $Y$, Tomonaga M: The growth inhibitory factor that is deficient in the Alzheimer's disease brain is a 68 amino acid metallothionein-like protein. Neuron 1991, 7:337-347.
58. Frederickson CJ, Klitenick MA, Manton WI, Kirkpatrick JB: Cytoarchitectonic distribution of zinc in the hippocampus of man and the rat. Brain Res 1983, 273:335-339.

59. Budde T, Minta A, White JA, Kay AR: Imaging free zinc in synaptic terminals in live hippocampal slices. Neuroscience 1997, 79:347-358.

60. Danscher G, Howell G, Perez-Clausell J, Hertel N: The dithizone, Timm's sulphide silver and the selenium methods demonstrate a chelatable pool of zinc in CNS. A proton activation (PIXE) analysis of carbon tetrachloride extracts from rat brains and spinal cords intravitally treated with dithizone. Histochemistry 1985, 83:419-422.

61. Frederickson CJ, Suh SW, Silva D, Thompson RB: Importance of zinc in the central nervous system: the zinc-containing neuron. J Nutr 2000, 130:1471S-1483S.

62. Assaf SY, Chung SH: Release of endogenous $\mathrm{Zn2}+$ from brain tissue during activity. Nature 1984, 308:734-736.

63. Frederickson CJ, Bush Al: Synaptically released zinc: physiological functions and pathological effects. Biometals 2001, 14:353-366.

64. Howell GA, Welch MG, Frederickson CJ: Stimulation-induced uptake and release of zinc in hippocampal slices. Nature 1984, 308:736-738.

65. Weiss JH, Hartley DM, Koh JY, Choi DW: AMPA receptor activation potentiates zinc neurotoxicity. Neuron 1993, 10:43-49.

66. Koh JY, Choi DW: Zinc toxicity on cultured cortical neurons: involvement of N-methyl-D-aspartate receptors. Neuroscience 1994, 60:1049-1057.

67. Dewar D, Underhill SM, Goldberg MP: Oligodendrocytes and ischemic brain injury. J Cereb Blood Flow Metab 2003, 23:263-274.

68. Chong ZZ, Kang JQ, Maiese K: Essential cellular regulatory elements of oxidative stress in early and late phases of apoptosis in the central nervous system. Antioxid Redox Signal 2004, 6:277-287.

69. Dressler J, Hanisch U, Kuhlisch E, Geiger KD: Neuronal and glial apoptosis in human traumatic brain injury. Int J Legal Med 2007, 121:365-375.

70. Rossi DJ, Brady JD, Mohr C: Astrocyte metabolism and signaling during brain ischemia. Nat Neurosci 2007, 10:1377-1386.

71. Frederickson CJ, Hernandez MD, McGinty JF: Translocation of zinc may contribute to seizure-induced death of neurons. Brain Res 1989, 480:317-321

72. Frederickson CJ, Hernandez MD, Goik SA, Morton JD, McGinty JF: Loss of zinc staining from hippocampal mossy fibers during kainic acid induced seizures: a histofluorescence study. Brain Res 1988, 446:383-386.

73. Lee JY, Cole TB, Palmiter RD, Koh JY: Accumulation of zinc in degenerating hippocampal neurons of ZnT3-null mice after seizures: evidence against synaptic vesicle origin. J Neurosci 2000, 20:RC79.

74. Suh SW, Chen JW, Motamedi M, Bell B, Listiak K, Pons NF, Danscher G, Frederickson CJ: Evidence that synaptically-released zinc contributes to neuronal injury after traumatic brain injury. Brain Res 2000, 852:268-273.

75. Tonder N, Johansen FF, Frederickson CJ, Zimmer J, Diemer NH: Possible role of zinc in the selective degeneration of dentate hilar neurons after cerebral ischemia in the adult rat. Neurosci Lett 1990, 109:247-252.

76. Cole TB, Wenzel HJ, Kafer KE, Schwartzkroin PA, Palmiter RD: Elimination of zinc from synaptic vesicles in the intact mouse brain by disruption of the ZnT3 gene. Proc Natl Acad Sci USA 1999, 96:1716-1721.

77. Lee JY, Kim JH, Palmiter RD, Koh JY: Zinc released from metallothionein-iii may contribute to hippocampal CA1 and thalamic neuronal death following acute brain injury. Exp Neurol 2003, 184:337-347.

78. Lee JY, Hwang JJ, Park MH, Koh JY: Cytosolic labile zinc: a marker for apoptosis in the developing rat brain. Eur J Neurosci 2006, 23:435-442.

79. Medvedeva YV, Lin B, Shuttleworth CW, Weiss JH: Intracellular Zn2+ accumulation contributes to synaptic failure, mitochondrial depolarization, and cell death in an acute slice oxygen-glucose deprivation model of ischemia. J Neurosci 2009, 29:1105-1114.

80. Choi DW: Glutamate neurotoxicity in cortical cell culture is calcium dependent. Neurosci Lett 1985, 58:293-297.

81. Pivovarova NB, Andrews SB: Calcium-dependent mitochondrial function and dysfunction in neurons. FEBS J.

82. Stork CJ, Li YV: Intracellular zinc elevation measured with a "calciumspecific" indicator during ischemia and reperfusion in rat hippocampus: a question on calcium overload. J Neurosci 2006, 26:10430-10437.

83. Brand-Schieber $\mathrm{E}$, Werner P: AMPA/kainate receptors in mouse spinal cord cell-specific display of receptor subunits by oligodendrocytes and astrocytes and at the nodes of Ranvier. Glia 2003, 42:12-24. 
84. Jourdain P, Bergersen LH, Bhaukaurally K, Bezzi P, Santello M, Domercq M, Matute C, Tonello F, Gundersen V, Volterra A: Glutamate exocytosis from astrocytes controls synaptic strength. Nat Neurosci 2007, 10:331-339.

85. Matute C, Alberdi E, Domercq M, Sanchez-Gomez MV, Perez-Samartin A, Rodriguez-Antiguedad A, Perez-Cerda F: Excitotoxic damage to white matter. J Anat 2007, 210:693-702

86. Kim TY, Yi JS, Chung SJ, Kim DK, Byun HR, Lee JY, Koh JY: Pyruvate protects against kainate-induced epileptic brain damage in rats. Exp Neurol 2007, 208:159-167.

87. Petty MA, Wettstein JG: Elements of cerebral microvascular ischaemia. Brain Res Brain Res Rev 2001, 36:23-34

88. Lee JY, Kim YH, Koh JY: Protection by pyruvate against transient forebrain ischemia in rats. J Neurosci 2001, 21:RC171.

89. Lee JM, Zipfel GJ, Park KH, He YY, Hsu CY, Choi DW: Zinc translocation accelerates infarction after mild transient focal ischemia. Neuroscience 2002, 115:871-878

90. Love S: Oxidative stress in brain ischemia. Brain Pathol 1999, 9:119-131.

91. Lobner D, Canzoniero LM, Manzerra P, Gottron F, Ying H, Knudson M, Tian M, Dugan LL, Kerchner GA, Sheline CT, et al: Zinc-induced neuronal death in cortical neurons. Cell Mol Biol (Noisy-le-grand) 2000, 46:797-806.

92. Boya P, Kroemer G: Lysosomal membrane permeabilization in cell death. Oncogene 2008, 27:6434-6451.

93. Johansson AC, Appelqvist H, Nilsson C, Kagedal K, Roberg K, Ollinger K: Regulation of apoptosis-associated lysosomal membrane permeabilization. Apoptosis 2010, 15:527-540.

94. Shacka JJ, Klocke BJ, Roth KA: Autophagy, bafilomycin and cell death: the "a-B-cs" of plecomacrolide-induced neuroprotection. Autophagy 2006, 2:228-230.

95. Shacka JJ, Klocke BJ, Shibata M, Uchiyama Y, Datta G, Schmidt RE, Roth KA: Bafilomycin A1 inhibits chloroquine-induced death of cerebellar granule neurons. Mol Pharmacol 2006, 69:1125-1136.

96. Yamashima T, Kohda Y, Tsuchiya K, Ueno T, Yamashita J, Yoshioka T, Kominami E: Inhibition of ischaemic hippocampal neuronal death in primates with cathepsin B inhibitor CA-074: a novel strategy for neuroprotection based on 'calpain-cathepsin hypothesis'. Eur J Neurosci 1998, 10:1723-1733.

97. Gardner OS, Shiau CW, Chen CS, Graves LM: Peroxisome proliferatoractivated receptor gamma-independent activation of p38 MAPK by thiazolidinediones involves calcium/calmodulin-dependent protein kinase II and protein kinase R: correlation with endoplasmic reticulum stress. J Biol Chem 2005, 280:10109-10118.

98. Hung JH, Su IJ, Lei HY, Wang HC, Lin WC, Chang WT, Huang W, Chang WC, Chang YS, Chen CC, et al: Endoplasmic reticulum stress stimulates the expression of cyclooxygenase- 2 through activation of NF-kappaB and pp38 mitogen-activated protein kinase. J Biol Chem 2004, 279:46384-46392.

99. Inanami O, Ohta T, Ito S, Kuwabara M: Elevation of intracellular calcium ions is essential for the $\mathrm{H} 2 \mathrm{O} 2$-induced activation of SAPK/JNK but not for that of p38 and ERK in Chinese hamster V79 cells. Antioxid Redox Signal 1999, 1:501-508.

100. Welihinda AA, Tirasophon W, Kaufman RJ: The cellular response to protein misfolding in the endoplasmic reticulum. Gene Expr 1999, 7:293-300.

101. Kim I, Xu W, Reed JC: Cell death and endoplasmic reticulum stress: disease relevance and therapeutic opportunities. Nat Rev Drug Discov 2008, 7:1013-1030.

102. Galluzzi L, Morselli E, Vicencio JM, Kepp O, Joza N, Tajeddine N, Kroemer G: Life, death and burial: multifaceted impact of autophagy. Biochem Soc Trans 2008, 36:786-790.

103. Kim I, Rodriguez-Enriquez S, Lemasters JJ: Selective degradation of mitochondria by mitophagy. Arch Biochem Biophys 2007, 462:245-253.

104. Klionsky DJ: The molecular machinery of autophagy: unanswered questions. J Cell Sci 2005, 118:7-18.

105. Cuervo AM: Autophagy: in sickness and in health. Trends Cell Biol 2004, 14:70-77.

106. Bampton ET, Goemans CG, Niranjan D, Mizushima N, Tolkovsky AM: The dynamics of autophagy visualized in live cells: from autophagosome formation to fusion with endo/lysosomes. Autophagy 2005, 1:23-36.

107. Gimenez-Xavier P, Francisco R, Santidrian AF, Gil J, Ambrosio S: Effects of dopamine on LC3-II activation as a marker of autophagy in a neuroblastoma cell model. Neurotoxicology 2009, 30:658-665.
108. Brayer KJ, Kulshreshtha S, Segal DJ: The protein-binding potential of $\mathrm{C} 2 \mathrm{H} 2$ zinc finger domains. Cell Biochem Biophys 2008, 51:9-19.

109. Cousins RJ, Liuzzi JP, Lichten LA: Mammalian zinc transport, trafficking, and signals. J Biol Chem 2006, 281:24085-24089.

110. Krezel A, Hao Q, Maret W: The zinc/thiolate redox biochemistry of metallothionein and the control of zinc ion fluctuations in cell signaling. Arch Biochem Biophys 2007, 463:188-200.

111. Maret W: Zinc coordination environments in proteins as redox sensors and signal transducers. Antioxid Redox Signal 2006, 8:1419-1441.

112. Maret W: Metallothionein redox biology in the cytoprotective and cytotoxic functions of zinc. Exp Gerontol 2008, 43:363-369.

113. Pedersen MO, Larsen A, Stoltenberg M, Penkowa M: Cell death in the injured brain: roles of metallothioneins. Prog Histochem Cytochem 2009, 44:1-27.

114. Chung RS, Fung SJ, Leung YK, Walker AK, McCormack GH, Chuah MI, Vickers JC, West AK: Metallothionein expression by NG2 glial cells following CNS injury. Cell Mol Life Sci 2007, 64:2716-2722.

115. Bremner I: Interactions between metallothionein and trace elements. Prog Food Nutr Sci 1987, 11:1-37.

116. Sato M, Bremner I: Oxygen free radicals and metallothionein. Free Radic Biol Med 1993, 14:325-337.

117. Ambjorn M, Asmussen JW, Lindstam M, Gotfryd K, Jacobsen C, Kiselyov W, Moestrup SK, Penkowa M, Bock E, Berezin V: Metallothionein and a peptide modeled after metallothionein, EmtinB, induce neuronal differentiation and survival through binding to receptors of the lowdensity lipoprotein receptor family. J Neurochem 2008, 104:21-37.

118. Asmussen JW, Von Sperling ML, Penkowa M: Intraneuronal signaling pathways of metallothionein. J Neurosci Res 2009, 87:2926-2936.

119. Haase H, Rink L: Signal transduction in monocytes: the role of zinc ions. Biometals 2007, 20:579-585.

120. Leung YK, Pankhurst M, Dunlop SA, Ray S, Dittmann J, Eaton ED, Palumaa P, Sillard R, Chuah MI, West AK, et al: Metallothionein induces a regenerative reactive astrocyte phenotype via JAK/STAT and RhoA signalling pathways. Exp Neurol 2010, 221:98-106.

121. Bell SG, Vallee BL: The metallothionein/thionein system: an oxidoreductive metabolic zinc link. Chembiochem 2009, 10:55-62.

122. Ding ZC, Ni FY, Huang ZX: Neuronal growth-inhibitory factor (metallothionein-3): structure-function relationships. FEBS J 2010, 277:2912-2920.

123. Faller $P$ : Neuronal growth-inhibitory factor (metallothionein-3): reactivity and structure of metal-thiolate clusters. FEBS J 2010, 277:2921-2930.

124. Nordberg M: Metallothioneins: historical review and state of knowledge. Talanta 1998, 46:243-254.

125. Garrett SH, Sens MA, Shukla D, Nestor S, Somji S, Todd JH, Sens DA: Metallothionein isoform 3 expression in the human prostate and cancerderived cell lines. Prostate 1999, 41:196-202.

126. Garrett SH, Sens MA, Todd JH, Somji S, Sens DA: Expression of MT-3 protein in the human kidney. Toxicol Lett 1999, 105:207-214.

127. Hoey JG, Garrett SH, Sens MA, Todd JH, Sens DA: Expression of MT-3 mRNA in human kidney, proximal tubule cell cultures, and renal cell carcinoma. Toxicol Lett 1997, 92:149-160.

128. Moffatt $P$, Seguin $C$ : Expression of the gene encoding metallothionein-3 in organs of the reproductive system. DNA Cell Biol 1998, 17:501-510.

129. Sewell AK, Jensen LT, Erickson JC, Palmiter RD, Winge DR: Bioactivity of metallothionein-3 correlates with its novel beta domain sequence rather than metal binding properties. Biochemistry 1995, 34:4740-4747.

130. Fitzgerald M, Nairn P, Bartlett CA, Chung RS, West AK, Beazley LD: Metallothionein-IIA promotes neurite growth via the megalin receptor. Exp Brain Res 2007, 183:171-180.

131. Asmussen JW, Ambjorn M, Bock E, Berezin V: Peptides modeled after the alpha-domain of metallothionein induce neurite outgrowth and promote survival of cerebellar granule neurons. Eur J Cell Biol 2009, 88:433-443.

132. Arai Y, Uchida Y, Takashima S: Developmental immunohistochemistry of growth inhibitory factor in normal brains and brains of patients with Down syndrome. Pediatr Neurol 1997, 17:134-138.

133. Isumi H, Uchida Y, Hayashi T, Furukawa S, Takashima S: Neuron death and glial response in pontosubicular necrosis. The role of the growth inhibition factor. Clin Neuropathol 2000, 19:77-84. 
134. Kawashima T, Doh-ura K, Torisu M, Uchida Y, Furuta A, Iwaki T: Differential expression of metallothioneins in human prion diseases. Dement Geriatr Cogn Disord 2000, 11:251-262.

135. Erickson JC, Hollopeter G, Thomas SA, Froelick GJ, Palmiter RD: Disruption of the metallothionein-III gene in mice: analysis of brain zinc, behavior, and neuron vulnerability to metals, aging, and seizures. J Neurosci 1997, 17:1271-1281.

136. Carrasco J, Penkowa M, Giralt M, Camats J, Molinero A, Campbell IL, Palmiter RD, Hidalgo J: Role of metallothionein-III following central nervous system damage. Neurobiol Dis 2003, 13:22-36.

137. Puttaparthi K, Gitomer WL, Krishnan U, Son M, Rajendran B, Elliott JL: Disease progression in a transgenic model of familial amyotrophic lateral sclerosis is dependent on both neuronal and non-neuronal zinc binding proteins. J Neurosci 2002, 22:8790-8796.

138. Ceballos D, Lago N, Verdu E, Penkowa M, Carrasco J, Navarro X, Palmiter $\mathrm{RD}$, Hidalgo J: Role of metallothioneins in peripheral nerve function and regeneration. Cell Mol Life Sci 2003, 60:1209-1216.

139. Yogalingam $G$, Pendergast AM: Abl kinases regulate autophagy by promoting the trafficking and function of lysosomal components. J Biol Chem 2008, 283:35941-35953.

doi:10.1186/1756-6606-3-30

Cite this article as: Lee and Koh: Roles of zinc and metallothionein-3 in oxidative stress-induced lysosomal dysfunction, cell death, and autophagy in neurons and astrocytes. Molecular Brain 2010 3:30.

\section{Submit your next manuscript to BioMed Central and take full advantage of:}

- Convenient online submission

- Thorough peer review

- No space constraints or color figure charges

- Immediate publication on acceptance

- Inclusion in PubMed, CAS, Scopus and Google Scholar

- Research which is freely available for redistribution

Submit your manuscript at www.biomedcentral.com/submit
Ciomed Central 